\begin{tabular}{l|c|c|}
\hline & International Journal of Current Research in \\
Biosciences and Plant Biology \\
\hline EXCELLENT \\
PUBLISHERS
\end{tabular}

\title{
Evaluation of Antifungal Activities of Four Plants Extract against Fungi Responsible for Corn Leaf Diseases
}

\author{
Soro Kouo-N'Golo*, Daniel Kra Kouamé and Hortense Atta Diallo
}

Unité Santé des Plantes, Université Nangui Abrogoua, Côte d'Ivoire

${ }^{*}$ Corresponding author.

\begin{tabular}{|c|c|}
\hline Article Info & ABSTRACT \\
\hline $\begin{array}{l}\text { Date of Acceptance: } \\
\text { 20 June } 2018\end{array}$ & \multirow{4}{*}{$\begin{array}{l}\text { In Côte d'Ivoire, corn (Zea mays) leaf diseases, due to fungal reduced significantly the } \\
\text { yield. In order to control these fungi responsible of corn leaves diseases, an } \\
\text { identification of the main pathogens was done. Antifungal activity of four plants } \\
\text { (Azadirachta indica, Chromolaena odorata, Ricinus communis and Nicotiana tabacum) were } \\
\text { tested in vitro and in vivo against fungi responsible for corn leaf diseases. The } \\
\text { pathogenicity test showed that the fungus Helminthosporium sp. was the most virulent } \\
\text { followed by Curvularia sp. All plants aqueous extract tested in this study inhibited } \\
\text { spore germination of fungi responsible for corn leaf diseases. } R \text {. communis was the most } \\
\text { effective aqueous extract against pathogens suppressing totally their conidia } \\
\text { germination. The treatment of corn plot with Azadirachta indica and Ricinus communis } \\
\text { reduced significantly incidence and severity of corn leaf diseases. These effective plant } \\
\text { extracts may contribute to development of potentially effective alternative fungicide to } \\
\text { control corn leaf diseases. }\end{array}$} \\
\hline $\begin{array}{l}\text { Date of Publication: } \\
\text { 06 July } 2018\end{array}$ & \\
\hline Keywords & \\
\hline $\begin{array}{l}\text { Corn leaf } \\
\text { Pathogen } \\
\text { Plant extr } \\
\text { Zea mays }\end{array}$ & \\
\hline
\end{tabular}

\section{Introduction}

Corn (Zea mays L.) is the third most widely grown grain crop in the world after wheat and rice (FAO, 2014). Corn is become an economically attractive crop for farmers across West African countries. In Côte d'Ivoire, corn is the country's second-largest cereal crop after rice. Its national production is estimated at $654738 \mathrm{t}$ for an area of 335000 ha (FAO, 2014). This production comes mainly from the center and north of the country where it is the staple food of the local population. Corn plays a predominant role as a subsistence crop, commercial and socio-cultural. It is present in all rural areas (Kouakou et al., 2010).

Despite its importance, corn production is still insufficient to meet national needs (Yéo, 2011). Indeed, Côte d'Ivoire remains dependent on the outside to meet the growing demand of the population (Kouassi, 2008). Several reasons could explain this insufficiency. Corn crop is further affected by several leaf diseases, which can cause significant damage to yield and grain quality. In 
particular, corn is susceptible to anthracnose which is caused by Colletotrichum graminicola and is characterized as one of the main foliar diseases. Anthracnose symptoms vary widely depending on numerous factors such as genotype, age of plant and environmental conditions; small oval or elongated water-soaked spots which enlarge up to $15 \mathrm{~mm}$ long appear on leaves; lesions develop a tan center and red-brown or orange border; lesions may coalesce to form large necrotic patches; severely infected leaves on susceptible hybrids may wither and die; fungal fruiting bodies develop on dead tissues and may produce pink or orange spore masses; the fungus may also cause top dieback and stalk rot. It is the same for Fusarium wilt, which is very important disease in corn monoculture. Rust and blotch are also responsible for many losses (Scauflaire et al., 2009).

To overcome these many difficulties encountered during the cultivation of corn, different methods of struggle are used. The most widely used control method is chemical control. However, the damage recorded in human health and on the environment, due to the use of conventional pesticides are frequent (Aubertot et al., 2005). Faced with these disadvantages, new non-chemical control methods are recommended. These include the use of plant extract, an alternative to the chemical control that pollutes and eventually leads to resistance in pathogens and residues in products (Amienyo and Ataga, 2007).

Studies have shown that some plant extracts have antifungal activities (Monisha, 2013). Extracts from the leaves of Azadirachta indica (neem), Chromolaena odorata, Ricinus communis and Nicotiana tabacum have shown antifungal properties against many fungal species responsible for diseases in cultivated plants (Bassey et al., 2012; Khursheed et al., 2012; Bayaso et al., 2013).

The objective of this study is to improve maize production through the use of plant extracts for the control of corn leaf diseases caused by pathogenic fungi.

\section{Materials and methods}

\section{Isolation and identification of the pathogens}

Samples of with symptoms of corn leaf diseases caused by fungi were collected from farms in Korhogo (savannah zone in Côte d'Ivoire). Pieces of diseased corn leaves were surface sterilized by immersion in 5\% sodium hypochlorite $(\mathrm{NaOCl})$ solution for $5 \mathrm{~min}$ followed by washing (three times) in sterilized distilled water. They were then dried in a sterile Lamina flow hood, placed on Potato Dextrose Agar (PDA) in Petri dishes and incubated at $28 \pm 2^{\circ} \mathrm{C}$. Mycelial growths from the plated tissues were transferred (picked with flamed needle from the periphery of growth) to fresh PDA plates. Sub-culturing was carried out to obtain pure isolates which were maintained on PDA. The pure fungi colonies were identified on the basis of their morphological characters. The frequency of each isolated fungus was calculated by using the following formula (1):

$$
F=\frac{\mathrm{Nf}}{\mathrm{Nt}} \times 100
$$

Where, F: Frequency (\%), Nf: Number of colonies of a particular fungi, Nt: total number of colonies.

\section{Pathogenicity test of isolated fungi on leaves parts}

Fungi isolates from leaves showing disease symptoms with 7-day-old on PDA were used for the pathogenicity test. Healthy young leaves of corn to be inoculated were surfaced sterilized with $5 \%$ sodium hypochlorite and then washed three times in sterile distilled water and dried with sterile filter paper. The surfaces of the healthy tissues were inoculated with a mycélial plug $(5 \mathrm{~mm}$ in diameter) of each fungal species. Healthy tissues inoculated with PDA plug served as control. There were three replicates of each isolated fungi. The inoculated leaves were kept in laboratory temperature $(27 \pm$ $1^{\circ} \mathrm{C}$ ). Symptoms on inoculated leaves were recorded 5 days after inoculation (d.a.i.) and reisolation, according to Koch's postulates, was made 
from all resulting lesions. The lesion diameter was measured 5 days after inoculation and the mean diameter of lesions was calculated.

\section{In vitro efficacy of plant extracts against spores germination of corn leaf diseases fungi}

\section{Preparation of extracts}

Fresh leaves of four plants, Azadirachta indica, Chromolaena odorata, Nicotiana tabacum and Ricinus communis were collected. The collected leaves was carried in polyethylene bags to the laboratory, washed with tap water, disinfected by immersion in $2 \%$ sodium hypochlorite solution for $30 \mathrm{~min}$, rinsed with sterile distilled water to eliminate residual hypochlorite and dried in shade for 23 days. The plant materials (leaves) were crushed into a fine powder with the help of grinder. Leaves extracts were prepared by soaking $100 \mathrm{~g}$ of dry powder from each plant species in 11 of tap water with stirring for $48 \mathrm{~h}$. The supernatants of aqueous extracts were sterilized by passing through double layers of muslin and finally filtered again through Whatman filter paper No. (4). Three concentrations $(20,40,60 \mathrm{~g} / \mathrm{l})$ were prepared by dissolving requisite volume of each plant extract solution stock $(100 \mathrm{~g} / \mathrm{l})$ in distilled water.

\section{Assessment of conidia germination}

For the germination test, conidial suspensions were obtained by flooding 12-day old colonies of each pathogens with sterile distilled water and agitating the surface with a glass rod. The conidial suspension was filtered through sterile muslin cloth and then adjusted to $10^{6}$ conidia/ml using the haemocymeter. The different concentrations $20 ; 40$ and $60 \mathrm{~g} / \mathrm{l}$ of each stock leaves aqueous extract were incorporeted into the liquid medium (distilled water + glucose) to test the sensitivity of the conidia. The liquid medium containing neither aqueous extract served as control. After $24 \mathrm{~h}$ incubation at $25{ }^{\circ} \mathrm{C}$, about 200 conidia per replicate were examined microscopically (Optika). The number of germinated conidia (with germ tube longer than two times of their diameters of corresponding conidia) for each treatment was counted and the respective percentage of inhibition of germination was calculated according to the formula (2). Each treatment was replicated three times and the experiment was conducted twice.

$$
P i s=\frac{N_{0}-N_{c}}{N_{0}} \times 100
$$

Where, No is the number of fungal conidia germination in the control, Nc is the number of fungal conidia germination in treated leaves aqueous extract

\section{In vivo efficacy of plant extracts against corn leaf disease caused by fungi}

The experimental design was a randomized block that was repeated in "Sets". Five "Sets" with three replications were used, and each "Set" contained 160 plants. The lines were cultivated in rows that were $2.40 \mathrm{~m}$ long and spaced $0.90 \mathrm{~m}$ from each other with 15 plants spaced $0.20 \mathrm{~m}$ apart in each row. Three seeds were sown in each hole at a depth of $0.05 \mathrm{~m}$, and at 45 days after emergence, treatment by spraying with the aqueous maceration of the dried leaf powders of (A. indica, C. odorata, $R$. communis and $N$. tabacum) at a concentration of $60 \mathrm{~g} / \mathrm{l}$ was carried out. The corn plots were treated once a week until the ears were ripe. For the control plot no treatment was done. Disease incidence was determined as the percent of infected leaves based on the number of leaves showing symptoms of corn leaf diseases. The severity of the disease was estimated by modifying the scale notes adopted by Notteghem et al. (1980). The severity index was calculated according to the formula (3):

$$
\text { Is }=\frac{\text { Xi. ni }}{9 \mathrm{Nt}} \times 100
$$

Where, Is: index of severity of the disease; Xi: disease severity; ni: plants effectif; $\mathbf{N t}$ : total effectif of plants; 9: highest severity score on the scale. 


\section{Statistical analysis}

All experiments were conducted in four replicates for each treatment and the data were reported as mean $\pm \mathrm{SE}$ (standard error). The data were also analyzed statistically using One-way analysis of variance (ANOVA) and differences among the means were determined for significance at $P \leq 0.05$ (Statistic 7.1).

\section{Results}

\section{Fungi isolated from corn leaf diseases}

Different fungi were successfully isolated from corn leaf diseases included, Fusarium sp., Colletotrichum sp., Helminthosporium sp., Pestalotiopsis sp., Puccinia sorghi, Curvularia sp., Apergillus sp. and Nigrospora sp. After 7 days on PDA, Fusarium sp and Colletotrichum sp. showed fluffy grey colonies with concentric growth. These fungi were associated with symptoms of apical blade dryness of corn leaves. The mycelium of Curvularia sp. was dark green on the upper face with a concentric growth. Conidia were spindleshaped, dark brown in the center and clear at the ends. Curvularia sp., Pestalotiopsis sp. and Nigrospora $\mathrm{sp}$. were associated with the black spot symptom of corn leaves. Helminthosporium sp., showed black mycelium. Puccinia sorghi showed red pustules with oval shapes and has been isolated from leaves showing the symptoms of rust.

\section{Frequency of isolated fungi}

Frequency of isolated fungi ranged from $2.43 \%$ to $68.62 \%$. Puccinia sorghi had the highest isolation rate $(68.62 \%)$ followed by Curvularia sp. (34.73\%) and Helminthosporium sp. (33.33\%). Pestalotiopsis sp. and Aspergillus sp. had the lowest isolation rates $(2.78 \%)$ and Fusarium sp. (11.12\%), Nigrospora sp. $(8.33 \%)$ had intermediate isolation rates (Fig. 1).

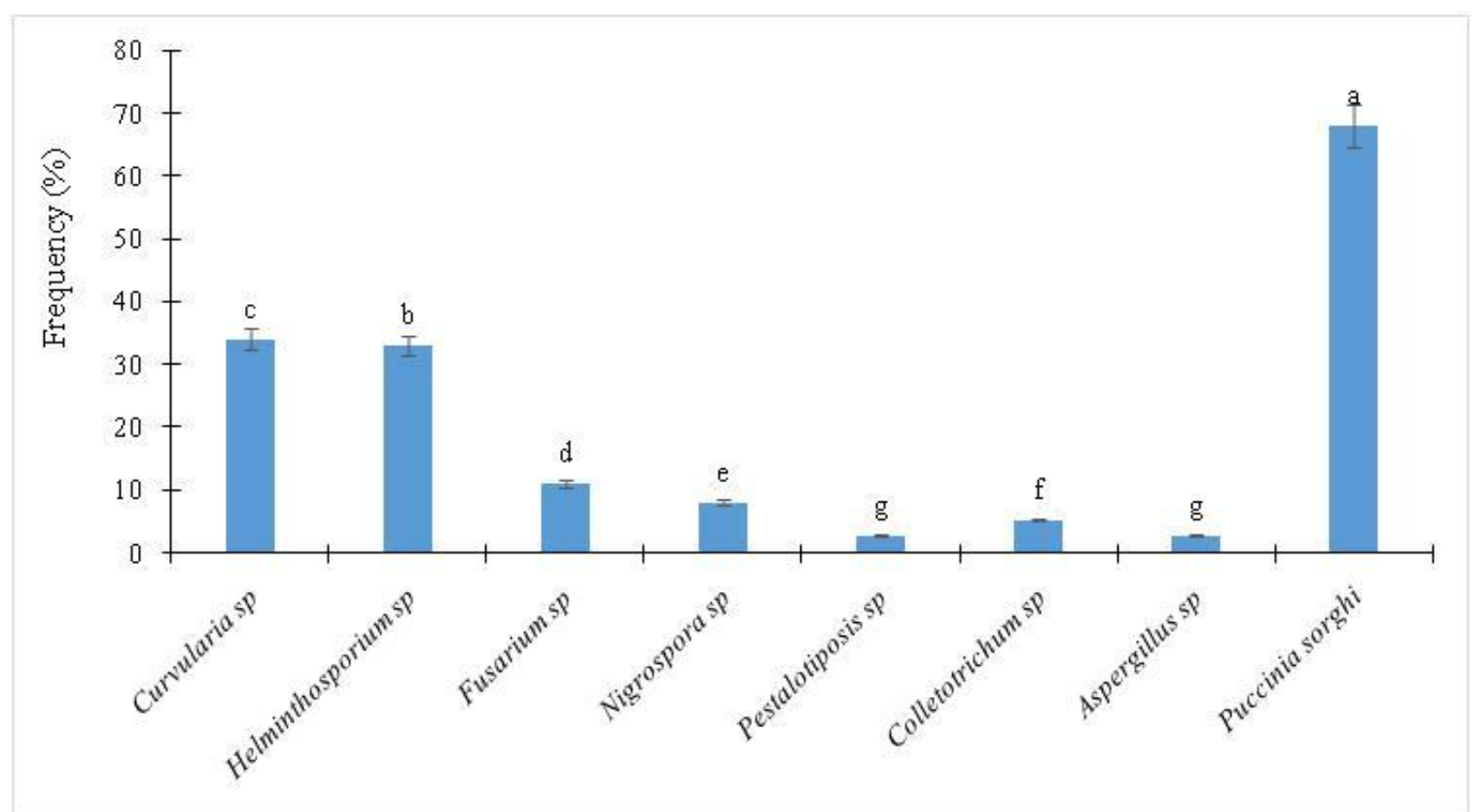

Fig. 1: Frequency of Fungi isolated from corn leaf diseases. Bands with the same standard deviation letter are not statistically different according to the 5\% Fisher LSD test.

\section{Pathogenicity of isolated fungi}

Inoculation with different fungi on fresh corn leaves revealed different types of symptoms. Symptoms induced by inoculated fungi varied according to the fungal species. Leaves inoculated with 
Helminthosporium sp. presented four types of symptoms. These are elongated brown spots, lesion of the main vein, local discoloration of the leaf (small circular yellow spots) and apical desiccation of the limb. The fungi Curvularia sp. caused black spots on loose leaves. Fusarium sp., caused small water soaked lesions and the lesions turned into yellow spots (Fig. 2). Mean diameter of symptoms varied between 0 and $3.5 \mathrm{~cm}$. The largest diameter was obtained with Helminthosporium $(3.5 \mathrm{~cm})$ and the smallest diameter was obtained with Fusarium $(1.5 \mathrm{~cm})$. No symptoms were observed in the controls.

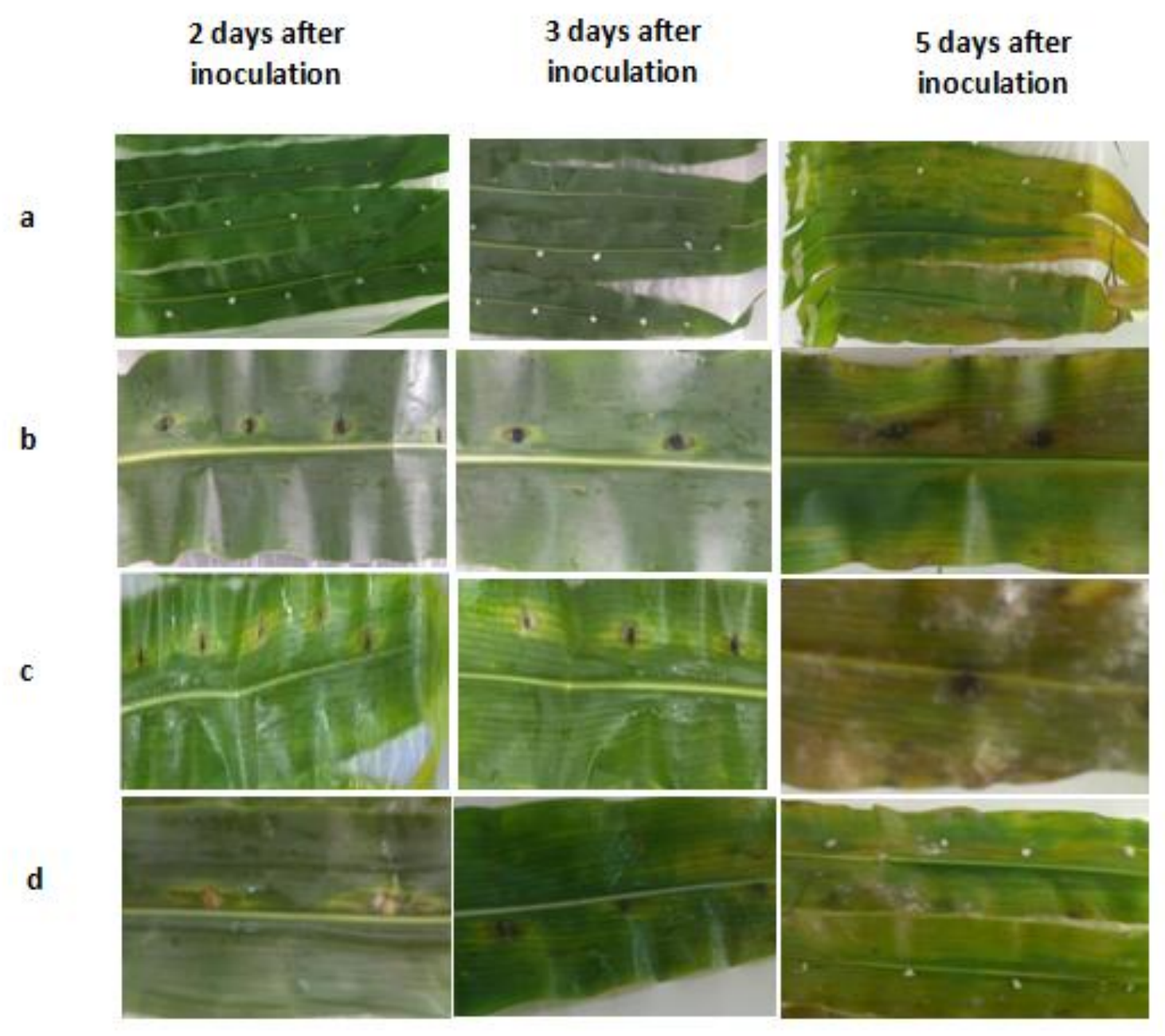

Fig. 2: Corn leaf lesions caused by inoculated fungi. a: Control; b: Curvularia sp.; c : Helminthosporium sp.; d: Fusarium sp.

\section{In vitro effect of aqueous extracts on spore germination}

Aqueous extracts of Azadirachta indica, Chromolaena odorata, Nicotiana tabacum, and Ricinus communis showed an inhibitory effect on the germ tube length of different fungi conidia. Statistical analyzes showed a significant difference between the inhibition rates of germination induced by all the extracts used. Inhibition rates of germ tube length ranged from $49.46 \%$ to $100 \%$ depending on plant extracts. Inhibition rates were greater than $50 \%$ for all extracts except $C$. odorata on the strain of Fusarium sp. (49.46\%) (Table 1). The extract of $R$. communis totally inhibited germination of Curvularia sp. conidia and Fusarium sp. (100\%). The inhibitory effect decreases slightly with Helminthosporium sp. (94.43\%). 
Table 1. Effect of plant aqueous extracts on conidia germination of pathogenic fungi.

\begin{tabular}{llll}
\hline \multirow{2}{*}{ Plant species } & \multicolumn{2}{l}{ Inhibition rate (\%) } & \\
\cline { 2 - 4 } & Fusarium sp. & Helminthosporium sp. & Curvularia sp. \\
\hline Nicotiana tabacum & $64.41 \pm 4.23^{\mathrm{c}}$ & $68.62 \pm 4.61^{\mathrm{b}}$ & $60.49 \pm 8.85^{\mathrm{c}}$ \\
Chromolaena odorata & $49.46 \pm 6.26^{\mathrm{d}}$ & $67.90 \pm 2.69^{\mathrm{b}}$ & $60.45 \pm 6.83^{\mathrm{c}}$ \\
Ricinus communis & $100.00 \pm 0.00^{\mathrm{a}}$ & $94.43 \pm 1.66^{\mathrm{a}}$ & $100.00 \pm 0.00^{\mathrm{a}}$ \\
Azadirachta indica & $78.33 \pm 0.00^{\mathrm{b}}$ & $69.04 \pm 8.18^{\mathrm{b}}$ & $67.89 \pm 4.05^{\mathrm{b}}$ \\
\hline
\end{tabular}

Means within a column with the different letters are significantly different $(P<0.05)$.

\section{In vivo antifungal assay of plant extracts on maize leaves diseases}

Corn leaf diseases symptoms were observed on the different plots. Diseases incidence observed varied significantly $(P<0.05)$ according to the treatments carried out with the aqueous extracts. On control plots and those treated with extracts of $C$. odorata the disease incidence were respectively 70.59 and $62.17 \%$. On plots treated with extracts of $A$. indica and $R$. communis, disease incidence were respectively 36.19 and $26.46 \%$, (Fig. 3). The lowest corn leaf diseases incidence was obtained on the plot treated with $N$. tabacum (13.43\%). The levels of diseases severity varied significantly $(\mathrm{P}<0.05)$ according to the treatment of different aqueous plant extracts. The highest corn leaves diseases severity was observed on the plants treated with the $C$. odorata extract, while the lowest severity was recorded for N. tabacum (Fig. 4).

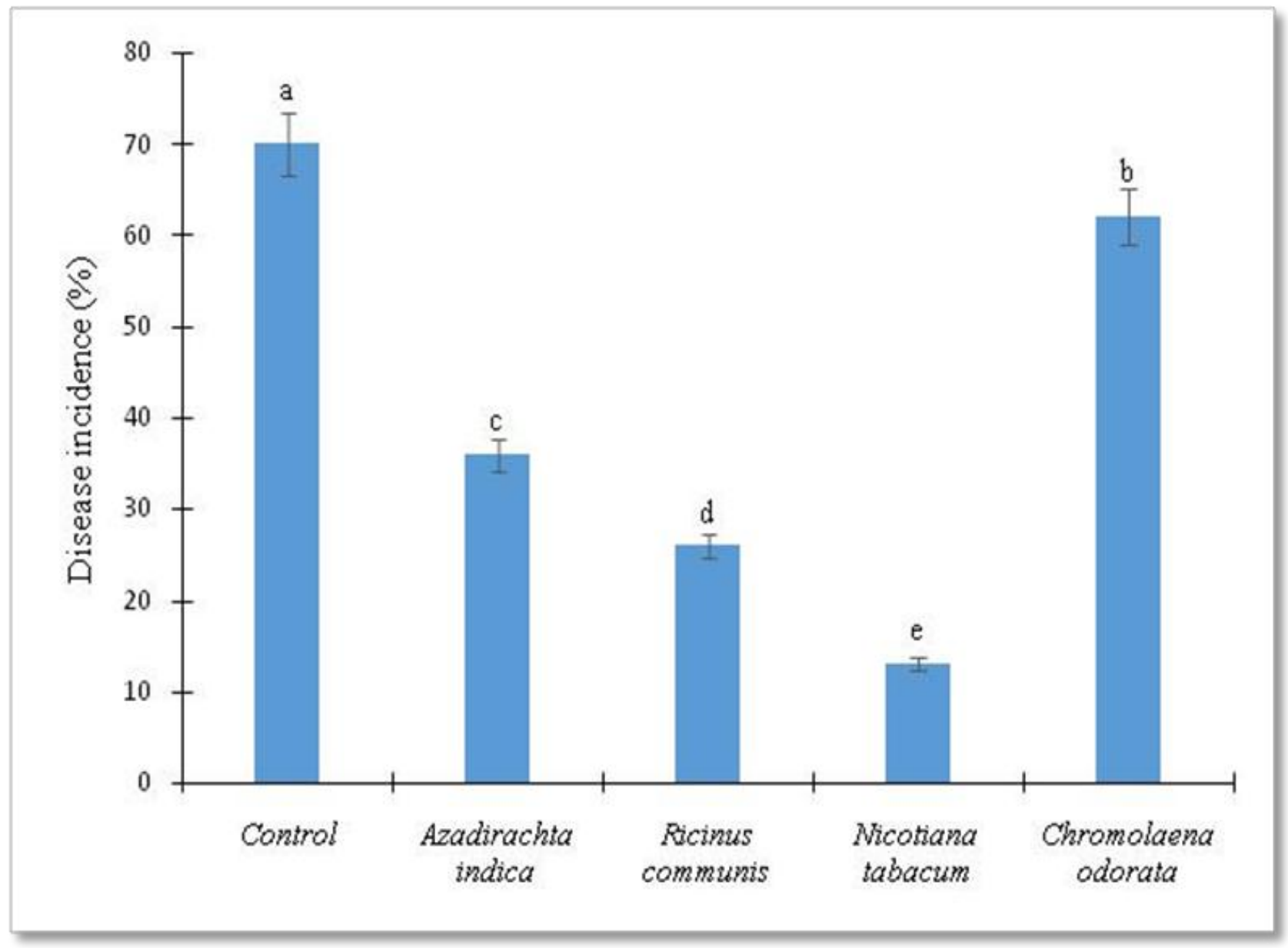

Fig. 3: Effect of plant extracts on corn leaf diseases incidence. Bars followed by common letters are not statistically different (LSD test, $P \leq 0.05$ ). 


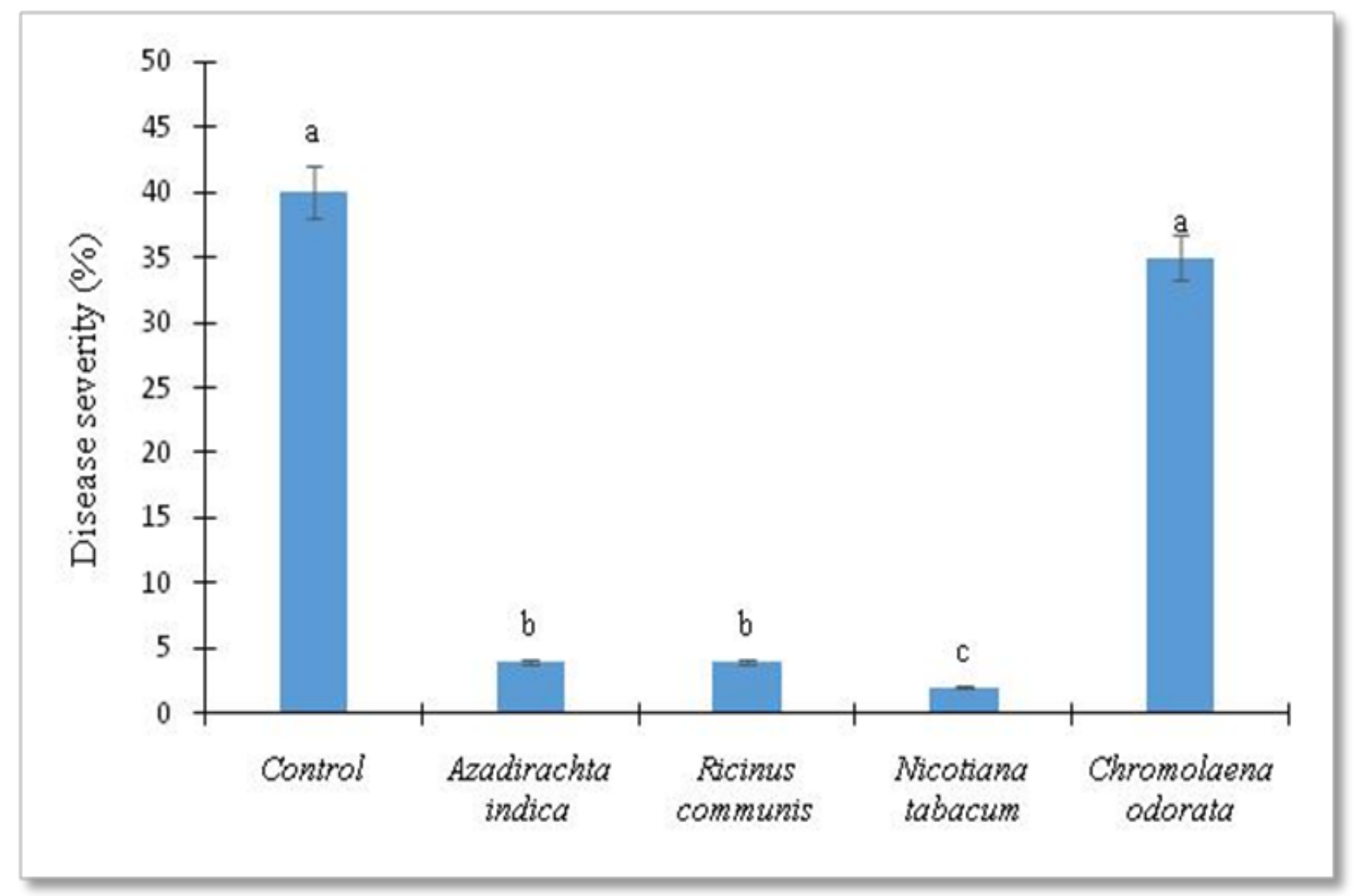

Fig. 4: Effect of plant extracts on corn leaf diseases severity. Bars followed by common letters are not statistically different (LSD test, $P \leq 0.05$ ).

\section{Discussion}

Eight fungal genera were obtained from corn leaves showed diseases symptoms and were identified as Pestalotiopsis, Puccinia sorghi, Helminthosporium, Curvularia, Nigrospora, Aspergillus, Colletotrichum and Fusarium. Howatt (2006) showed that in Canada Puccinia, Helminthosporium, Colletotrichum, Fusarium and Penicillium were associated with corn leaf diseases. Inoculations of the fungi Curvularia sp., Fusarium sp. and Helminthosporium sp. on the leaves revealed foliar disease symptoms, these results were falling in line with the study conducted by Bahous et al. (2008). Earlier studies conducted by Williams et al. (2007) revealed similar findings in which species of Fusarium were observed to infect maize leaves. Research conducted by Nguyen (2014) revealed also that Fusarium proliferatum and Fusarium verticillioides have the ability to establish infection and disease within maize via the leaf system. Recent studies in China showed an increase on the frequency of the fungus Curvularia lunata (Wakker) provoking diseases in maize cultivars (Gao et al., 2012). The pathogenicity of the Curvularia lunata isolates in maize plants was also confirmed by (Dalmarcia, 2017), in which typical symptoms were small circular spots on the inoculated leaves after the incubation period of $48 \mathrm{~h}$ later.

The aqueous extract of $A$. indica, C. odorata, $N$. tabacum and $R$. communis showed antifungal activity against Curvularia, Fusarium and Helminthosporium. This antifungal activity of these extracts could be due to their chemical compounds. Koumaglo et al. (2009) suggested that the aqueous extract of Chromolaena odorata has antifungal properties due to the presence of compounds such as phenols, tannins and flavonoids. Adjou et al. (2013) also showed the effectiveness of the extracts of ten medicinal plants including Chromolaena odorata which was among the most effective plants 
on the growth of toxinogenic molds responsible for the deterioration of peanut seeds in post harvesting in Benin. Avlessi et al. (2012) reported that $C$. odorata extract contains antifungal substances such as sesquiterpenes, monoterpenes, flavonoids and tannins, these substances have shown efficacy on many fungal strains such as Aspergillus ochraceus and Penicillium digitatum. In this study A. indica and $R$. communis extract was efficient on isolated fungi. Monisha et al. (2013) showed the in vitro efficacy of the aqueous extract of $R$. communis leaves against Aspergillus niger and Botryodiplodia theobromae. The antifungal properties of $R$. communis were also highlighted by Bayaso et al. (2013) on the early browning of tomatoes. The antifungal activity induced by the extract of $N$. tabacum was most effective compared to $R$. communis, A. indica. Lakjiri (2010) showed that $N$. tabacum extract contains phenols and alkaloids (0.5 to $2 \%$ ) including nicotine with a content of 85 to $95 \%$, these compounds induced the efficiency of this extract.

The effectiveness of plant extracts differs from one species of fungi to another and depends on the concentration for the same extract. Indeed, the results obtained show that Curvularia sp. is more sensitive. The incidence and severity of corn leaf disease symptoms varied with the extract used in treatment. Indeed, the difference could be explained by the insensitivity of certain fungal strains to the extracts.

\section{Conflict of interest statement}

Authors declare that they have no conflict of interest.

\section{References}

Adjou, S.E., Soumanou, M.M., 2013. Efficacité des extraits de plantes dans la lutte contre les moisissures toxinogènes isolés de l'arachide en post-récolte au Benin. J. Appl. Biosci. 70, 55555566.

Amienyo, C.A., Ataga, A.E. 2007 Use of indigenous plant extracts for the protection of mechanically injured sweet potato [Ipomoea batatas (L.) Lam.] tubers. Acad. J. Sci. Res. Essay. 2, 167-170.

Aubertot, J.N., Barbier, J. M., Capentier, A., Guichard, L., Savary, S., Savini, I., 2005. Réduire 1'utilisation des pesticides et en limiter les impacts environnementaux. Pesticide, agriculture et environnement $32 \mathrm{p}$.

Avlessi, F., Alitonou, G. A., Djenontin, T. S., Tchobo, F., 2012. Chemical composition and biological activities of the essential oil extracted from the fresh leaves of Chromolaena odorata (L. Robinson) growing in Benin ISCA. J. Biol. Sci. 1(3), 7-13.

Bahous, M., Ouazzani-Touhami, Douira, A., 2008. Survie de quelques pathogènes fongiques sur les feuilles de riz conservées au laboratoire. Rabat, Section Sciences de la Vie, 2008, n³0, 13-18 p. Bassey, I. N., Ogbemudia, F. O., Harold, K. O., Idung, K. E., 2012. Combined antifungal effects of extracts of Jatropha curcas and Chromolaena odorata on seed borne fungi of Solanum gilo Raddi. Bull. Environ. Pharmacol. Life Sci. 2(2), 13-17.

Bayaso, I., Nahunnaro, H., Gwary, D. M., 2013. Effects of aqueous extract of Ricinus communis on radial growth of Alternaria solani. Afr. J. Agric. Res. 8(37), 4541-4545.

Dalmarcia de Sousa, C. M., Talita, F. S., Pereira, Danival, J. S., Aloísio, F. C. J., Mateus, S. D., Ronice, A. V., Evelynne, U. L., Gil, R. S., 2017. Essential oil of Cymbopogon citratus on the control of the Curvularia leaf spot disease on maize. Medicines. 4, 62.

FAO, 2014. Production Yearbook, FAOSTAT database.

Gao, S., Liu, T., Li, Y., Wu, Q., Fu, K., Chen, J., 2012. Understanding resistant germplasminduced virulence variation through analysis of proteomics and suppression subtractive hybridization in a maize pathogen Curvularia lunata. Proteomics. 12, 3524-3535.

Howatt, S., 2006. Profil de la culture du maïs de grande culture de grande culture au Canada. Centre pour la lutte antiparasitaire Programme de réduction des risques liés aux pesticides Agriculture et Agroalimentaire Canada.

Khursheed, R., Naz, A., Naz, E., Sharif, H., 
Rizwani, G. H., 2012. Antibacterial, antimycelial and phytochemical analysis of Ricinus communis Linn., Trigonella foenum grecum Linn. and Delonix regia (Bojer ex Hook.) Raf. of Pakistan. Roman. Biotechnol. Lett. 17(3), 7237-7244.

Kouakou, C. K., Akanvou, L., Konan, Y. A., Mahyao, A., 2010. Stratégies paysannes de maintien et de gestion de la biodiversité du maïs (Zea mays L.) dans le département de Katiola, Côte d'Ivoire.

Kouassi, B. Y. (Ed.), 200). Les déterminants de la production agricole en Afrique de l'Ouest: Burkina Faso, Côte d'Ivoire, Ghana et Togo. Karthala Editions. 56 pp.

Koumaglo, K. H., Dotse, K., Bettini, F., Bayle, J. C., 2009. Composition chimique de l'huile essentielle de Chromolaena odorata (L) King et Robinson (Asteraceae) du Togo: Effets de séchage et du site de récolte. J. Soc. Ouest-Afr. Chem. 28, 11-16.

Lakjiri, S., 2010. Tabac et cancers urologiques. Thèse. $13 \mathrm{p}$.

Monisha, K., 2013. Effect of phytochemical constituents of Ricinus communis, Pterocarpus santalinus, Terminalia bellerica on antibacterial, antifungal and cytotoxic activity. Int. J. Toxicol. Pharmacol. Res. 5(2), 47-54.

Nguyen, T. T. X., 2014. Comparative studies on the infection and colonization of maize leaves by $F$ usarium graminearum, $F$. proliferatum and $F$. verticillioides Landwirtschaftlichen Fakultät der Rheinischen Friedrich Wilhelms Universität Bonn, Germany 33 p.

Notteghem, J. L., Andriatompo, G. M., Chatel, M., Dechanet, R., 1980. Techniques utilisées pour la sélection des variétés de riz possédant la résistance horizontale à la pyriculariose. Ann. Phytopathol. 12(3), 199-226.

Scauflaire, J., Munaut, F., 2009. Etat de la fusariose sur maïs en Wallonie. Guide Pratique. 35 p.

Williams, L. D., Glenn, A. E., Zimeri, A. M., Bacon, C. W., Smith, M. A., Riley, R. T., 2007. Fumonisin disruption of ceramide biosynthesis in maize roots and the effects on plant development and Fusarium verticillioides induced seedling disease. J. Agric. Food Chem. 55(8), 2937-2946.

Yéo, Y. A., 2011. Analyse de la compétitivité du maïs local en Côte d'Ivoire. 10 p.

\section{How to cite this article:}

Kouo-N'Golo, S., Kouamé, D. K., Diallo, H. A., 2018. Evaluation of antifungal activities of four plants extract against fungi responsible for corn leaf diseases. Int. J. Curr. Res. Biosci. Plant Biol. 5(7), 18-26. doi: https://doi.org/10.20546/ijcrbp.2018.507.003 